\title{
Using a preclinical approach to reveal potential mechanisms of ADRs to antidepressants in adolescents
}

\author{
Evangelia M Tsapakis
}

\author{
From $1^{\text {st }}$ International Congress on Neurobiology and Clinical Psychopharmacology and European \\ Psychiatric Association Conference on Treatment Guidance \\ Thessaloniki, Greece. 19-22 November 2009
}

A recent meta-analysis of the efficacy of all types of antidepressants in juvenile major depressive disorder patients [1] urged that additional research be undertaken to clarify the basis of limited responses in adolescents and children to antidepressant treatments considered standard in the treatment of adult major depressive disorder (MDD). Sprague-Dawley rats were treated chronically with fluoxetine, imipramine, tranylcypromine or vehicle control. Total RNA was extracted from brain cortices, cRNA was fragmented and hybridised to Affymetrix Rat Genome 2302.0 microarrays. A total of 24 microarrays were analysed (ie, 6 biological replicates in 4 treatment groups) and information on the probesets of interest was obtained using different websites. Taqman real-time qPCR methodology was used to validate the transcripts identified from the microarray data-analysis as the most significantly differentially expressed in response to treatment with imipramine or fluoxetine compared to vehicle. The relative expression of each gene was also determined. In both the imipramine- and fluoxetine-treated animals, expression of several genes was altered. These function in signal transduction (e.g., angiopoietin-like 4 protein), protein metabolism (e.g., sulfotransferase family $1 \mathrm{~A}$, phenol-preferring, member 1), cell survival (e.g., response gene to complement 32 , metallothionein 1a), and nuclear functions (e.g., similar to Cat eye syndrome critical region protein 2). Therefore, in the developing rodent cortex, antidepressants alter the expression of genes involved in signalling, cellular survival and protein metabolism, involved in critical functions including neuronal plasticity. These findings have implications for the

MRC SGDP Centre, Institute of Psychiatry at King's College London, UK mechanisms of ADRs to antidepressants in children and adolescents.

Published: 22 April 2010

Reference

1. Tsapakis E, Soldani F, Tondo L, Baldessarini R: Efficacy of antidepressants in juvenile depression: meta-analysis. Br J Psychiatry 2008, 193:10-17.

doi:10.1186/1744-859X-9-S1-S7

Cite this article as: Tsapakis: Using a preclinical approach to reveal potential mechanisms of ADRs to antidepressants in adolescents. Annals of General Psychiatry 2010 9(Suppl 1):S7.
Submit your next manuscript to BioMed Central and take full advantage of:

- Convenient online submission

- Thorough peer review

- No space constraints or color figure charges

- Immediate publication on acceptance

- Inclusion in PubMed, CAS, Scopus and Google Scholar

- Research which is freely available for redistribution

Submit your manuscript at www.biomedcentral.com/submit
C Biomed Central 